\title{
Making Race: \\ Examining the Power of Local Place \\ in Teacher Discourse in Mauritius
}

\author{
Elsa Wiehe \\ Mauritius
}

\begin{abstract}
Teaching to students' local experiences is a tenet of good teaching in many contexts. This study explores the ways eight educators use local meanings in discourse. Through ethnographic work in an elementary school in the township of Roche-Bois, Mauritius, I examine teachers' words about students' localities. Articulating critical discourse analysis with theories of space, I evaluate whether teachers' place-based meanings perpetuate or transform long-standing historical patterns of racialization associated with the town. The analysis identifies how processes of racialization take shape through place-based discourse. I draw implications for a critical pedagogy of the local to support decolonizing teacher knowledge.
\end{abstract}

KEYWORDS: Context-specific education, Racism, Place, Local, Discourse

\author{
Introduction and Objectives \\ Situating Main Concepts in the Literature \\ Findings \& Analysis \\ Conclusion \\ References \\ Author Contact
}

\section{Introduction and Objectives}

Across the globe, engaging with students' local experiences is axiomatic of good teaching (UNICEF, 2000), supported by several educational philosophies (Cole, 2008; Dewey, 1938; Gonzales, Moll, \& Amanti, 2005; Gruenewald, 2003; Gruenewald \& Smith, 2008; Nespor, 2008). As locality is so central to children's experiences, the ways teachers draw on place-based notions in day-to-day interactions need to be closely examined across contexts, and especially in socially marginalized spaces. However, some children occupy local places that are historically marginalized. In this study about students' local experiences in Roche Bois, Mauritius, a participant educator explained it this way: "There are lots of drugs and incidences of theft out here [in this town]. Despite this, we have to use students' local experiences. These things are a reality here." In this township perceived as ethnically Creole, where exploitative labor practices and environmental justice issues are common, educators' use of local examples in 
practice carries much weight. How do teachers speak about children's places in poor urban spaces? This study addresses that central question through ethnographic study of teachers' language of place in an elementary school in the town of Roche Bois, Mauritius.

Located in the outskirts of the Mauritian capital of Port Louis, the township of Roche Bois, although ethnically diverse, is perceived in the national imaginary as being primarily populated by "Creoles" (Boswell, 2006). In Mauritius, the identity category of "Creole" refers to the mixed descendants of African peoples who descended from enslaved peoples. They include Creoles of Mauritius, refugees from the Chagos islands, and Creoles of Rodrigues. Creoles are one of the most disenfranchised populations in Mauritius (Boswell, 2006; Truth and Justice Commission, 2011). Indians (both Hindu and Muslim) are the largest population; upper-class Indians have greater control of state agencies than other groups, and Indians are more represented in the teaching force. Economic power is shared by Whites and elite Indians (Bunwaree, 1997; Salverda, 2010). Mauritius is a highly segregated and unequal context where, paradoxically, making grievances on the basis of race is negatively branded as "communalism," which means that identitybased Creole movements have failed to bring key demands for equity in redistribution and representation (Fraser, Dahl, Stolz, \& Willig, 2004). In addition, no ethnic data have been collected on the national census since 1972, confining documentation of ethnic/racial discrimination to small scale and qualitative evidence. Since speaking of race and ethnic identity is branded as "communalist," the ways teachers engage with children's localities in the racialized township of Roche Bois need to be closely examined. This study thus analyzes how eight elementary school educators employ meanings of local place in everyday discourse. The key discursive aspect under study is the articulation of race through its association with the broader semantic category of local place.

In the next sections, I first show the importance of studying teachers' discourse on the local by providing background on the constructivist principle of local teaching in the literature and pointing to some issues in implementation. Discussing the fluidity of the concept of race, I establish that it is necessary to examine closely the way it articulates with other semantic categories of meaning such as place. Second, I propose an original methodology to analyze teacher discourse, articulating two seminal theorizations, Lefebvre's theory of space (1991) and Wodak's critical discourse analysis (CDA) (2009), to advance the study of the ways racialization happens through spatial discourse. Finally, after presenting findings on how Roche Bois educators speak about the local, I discuss implications for theorizing race as well as implications for decolonizing teacher knowledge, drawing on critical place-based education. 


\section{Situating Main Concepts in the Literature}

\section{Teaching through Students' Local Experiences}

There is a long history of educational thought that emphasizes the importance of building on students' local experiences. Dewey (1938) theorized that students learn because they relate new material to their past experiences. Progressive education should develop an "expression and cultivation of individuality," "free activity," and "learning through experience" (p.19). He spoke of the "intimate and necessary relation between processes of actual experience and education" (p. 20). Constructivist understandings of learning (Marlowe \& Paige, 2005) and research on the role of neuroscience and the brain in learning (Jensen, 2005; Willis, 2012) built on Dewey's insights, establishing as now firm pedagogical knowledge that teachers should connect new material with students' experiences, backgrounds, and contexts. This principle of teaching is especially important for teachers in urban settings across contexts where a longstanding disjuncture between home and schools has been identified (Delpit, 1995; Emdin, 2016; Steiner-Khamsi, 2015) resulting in a strong cultural disconnect between teachers and students.

The time-honored approach of funds of knowledge (FoK) aims at bridging this home-school gap in teacher knowledge. A project developed in the southwestern United States border region, FoK are "the historically accumulated and culturally developed bodies of knowledge and skills essential for individual functioning and well-being" (Moll, Amanti, Neff, \& Gonzales, 2005, p. 71). This perspective encourages teachers to value and draw on specific everyday practices that children generate in their households and localities, toward cultural responsiveness and enhanced student learning. The continued prevalence of the FoK approach in current educational thinking and action is testament to its importance, with teachers using the framework as an analytical tool to reflect on the ways their own life frames inform their identities (Varga-Dobai, 2018), to interpret their conversations with students (Hedges, 2015), to derive curriculum from high school students' life experiences while also drawing out their narratives (Hogg, 2016) or to highlight the importance of transnational students' cultural resources (Dabach \& Fones, 2016), among many other adaptations.

For teachers who draw on students' local experiences in pedagogical practice, there are some documented challenges in implementation. In an early reflection, Dewey cautioned against the power of the educator, because, as he expresses, teachers have inherent control over experience, and their practices have "directive value" toward the children (Dewey, 1938, p.21). Educators' own cultural repertoires shape their perspectives and in turn crucially affect their interpretation of what "local" means. Dewey notes that educators' successful engagement with children's experiences depends on their own background knowledge, saying that "the funded experience of the past" (p. 42, emphasis 
added) of the teacher should structure the learning experience of the student. Another challenge is highlighted in a recent study on funds of knowledge of students. Macias \& Lallas (2014) examine the ways funds of knowledge are understood by teachers and highlight inconsistencies between teachers' and families' interpretation of the cultural repertoire of resources of students. The authors show how teachers interpret a range of local themes such as friendships or family relationships in significantly different ways than families, thus resulting in a mismatch between the areas of life that are of value to students and that could be opportunities for responsive instruction. In another important review, Hogg (2011) points out that different definitions of FoK across the research make for difficulties in implementation in instruction. The review raises important questions, first about how to identify whose knowledge should be drawn on, whether it be that of students, families, or adults in the community, and second, about what should be the source of funds of knowledge, whether it be context, community, or schoolbased knowledges. Hogg thus points to a key implication that researchers must specify what is included as sources of knowledge.

This study explicitly addresses this last question by focusing on the ways teachers use language about the children's local township, contextualizing the research intentionally in the significant locality of Roche Bois. This purposeful place-based framing is underpinned by critical place-based education's emphasis on the importance of place-based specificity. A framework developed by Gruenewald (2003), a critical pedagogy of place brings together environmental place-based education's focus on local ecology and environment with critical pedagogy's emphasis on issues of power and difference in order to promote reinhabitation of spaces and decolonization of knowledge about spaces. A number of recent studies align with this call to localize teacher knowledge in the specific places of teaching with studies focused on teacher preparation for rural spaces (Eppley, Shannon, \& Gilbert, 2011) and for cities (e.g., Chicago: Matsko \& Hammerness, 2013; New York: Hammerness \& Craig, 2015).This place-based anchoring of teacher knowledge is especially critical when the local is a historically marginalized setting like Roche Bois.

\section{The Versatility of Racial Discourse in Specific Contexts}

This study examines place-based meanings in teacher discourse as they articulate with racial identity in Roche Bois. The modern concept of race, as a category of meaning, was historically created by White dominant groups for the purposes of exploitation (Aulette, 2017; Omi \& Winant, 2015), with variations across contexts. Race is thus a category that was created to function in the service of power. As power plays out very differently in different spaces, race and racism need to be examined as they take shape in specific places.

One way racial meanings remain powerful is that they are versatile. Race is rarely a category of meaning that stands on its own. Seminal theorizations of race have documented how race articulates with different semantic fields, including gender, class, and place (Stoler, 2002; Wodak \& Reisigl, 2001). Goldberg (1993) 
in particular describes the "chameleonic" quality of race. Stoler (2002) similarly discusses the elusiveness of race as "polyvalent mobility," taking up Foucault's idea to emphasize that racist discourse is mobile; it does not display consistent political interests in all historical situations and it lacks thematic unity. The versatile nature of race is often attributed to a distinction scholars make between a racism that was more overt in the past and that focused on somatic, biological characteristics and a "new racism" that is nuanced and that uses cultural codes (Gilroy, 1987; Sanchez, 2018; Stoler, 2002). In this view, racism reconfigured itself away from explicit normative judgments about the body and transferred itself to an intangible realm. Race, and racism, are constituted through versatile amalgams of meanings (including place) that need to be studied in specific contexts at specific times, and not taken as a-priori. The specific history of Roche Bois in Mauritius as detailed below is therefore a powerful force in shaping the ways place-based meanings occur in this context.

\section{Methodology}

\section{Access, Study Setting, Participants, \& Data Collection}

The entry point to this research stems from my situatedness as a Mauritian national. I grew up not far from Roche Bois and often passed it on the highway that divides the township. My commitment to the community started in my youth when I volunteered at a local parochial school. Knowing the educational issues of Roche Bois firsthand, I returned as a teacher educator and researcher with the goal of supporting teaching through close ethnographic work with teachers. Since Roche Bois has no high school, the focus became one of the local elementary schools. Following principles of ethical standards in research, I secured permission from the Ministry of Education to research for two trimesters, obtained informed consent from eight of the 16 total educators, ensuring anonymity of their names and respect for the privacy of their titles. This choice was also guided by the CDA lens detailed in the next section. CDA emphasizes the effects of language in use as opposed to the intentions, rationality, or psychology of speakers. I therefore refer to teachers in this study as educators, and when needing to differentiate them within same dialogue, I qualify them with letters.

The focus of the study was on upper-level grades, from $4^{\text {th }}$ to $6^{\text {th }}$. Since the subjects of literacy, history, and geography are taught more formally at these levels, the assumption was that this focus would yield greater instantiations of language about place. Most students in the classrooms were of Creole background, and most teachers identified as being of mixed Indian origin. Similar to the trends in urban schools in the United States where teachers do not live in the locality in which they teach, none of the educators lived locally, and most had been placed in this school by the Mauritian Ministry of Education. 
For seven months, using ethnographic methods, I documented educator discourse in classrooms, the schoolyard, and in daily whole-school assemblies. I rotated between six classrooms during science, history, and geography in addition to attending twice-daily whole-school assemblies. I observed, audio-recorded, transcribed, and "thickly described" (Geertz, 1973) educators' daily interactions and behaviors, paying attention to language. Since educators codeswitch extensively between Mauritian Kreol, French, and English during instruction, for the purpose of this article, I translated all educators' utterances from Mauritian Kreol and French to English. To contextualize teachers' discourse, I researched the larger spatial historical context of Roche Bois, gathering data from the National Archives and published literature to trace the historical changes in Roche Bois demographics. I supplemented the archival research with interviews with Roche Bois elders whom I contacted through the intermediary of a local nongovernmental organization. My conversations with local community leaders focused on their perceptions of the town in the national imaginary.

\section{Methodological-Theoretical Lens}

\section{Lefebvre's Concept of Space}

Places are not empty containers for the social but are discursively constructed in everyday interactions. This view is grounded in postmodern conceptions of space and place (Cresswell, 2004; de Cillia, Reisigl, \& Wodak, 1999; Gieseking et al., 2014; Lefebvre, 1991), which understand place as historically and politically situated constructions of meanings, instantiated in texts and social interactions. Specifically in this analysis, I use the seminal theorizations of Lefebvre (1991) who conceptualized space as constructed socially. For Lefebvre, there are three spatial elements produced simultaneously by social actors: perceived space, conceived space, and lived space. Perceived space is the space of the material dimensions of life and the social practices that produce it. Conceived space is the dominant space of representations produced by social engineers, i.e., the state, the schools, the media, and other powerful institutions. It is primarily concerned with maintaining the status quo and reproducing society. Lived space is a counterpoint to conceived space and is a space of resistance and potential transformation. Lived space opens moments of opportunity to redesign dominant conceived spaces for the transformation of perceived space.

While actual material (perceived) space around us is also a dimension of experience, this study is grounded in school-based discourses on space. I thus focus primarily on conceived and lived spaces as reproductive and transformative forces in the language of teachers. To operationalize Lefebvre's conceived and lived spaces, I put his understandings of space in dialogue with methodological 
insights from the Discourse Historical Approach (DHA) (Wodak \& Reisigl, 2009) which I expand on below.

\section{Wodak's Discourse Historical Approach}

Wodak and colleagues developed a brand of CDA called Discourse Historical Analysis (DHA) (de Cillia, Reisigl, \& Wodak, 1999; Wodak \& Reisigl, 2009). It gives attention to the examination of discourses in their historical-political contexts. In particular, I use their concept of "discursive strategies" as an analytical tool to examine how language "achieve(s) a particular social, political, psychological or linguistic aim" (Wodak \& Reisigl, 2001, p. 73). Strategies are thus interpretive mechanisms to examine the effects of educators' language. In particular, I focus on two discursive strategies as analytical tools for identity construction, examining them in tandem with Lefebvre's concepts of conceived and lived space: (a) Identity reproduction: how educators' language discursively perpetuates children's place-based identities and produces conceived (dominant) spaces; and (b) Identity transformation: how educators' language discursively changes children's place-based identities and produces lived (transformative) spaces. A short summary of the methodological-theoretical alignment I developed is shown below.

Table 1

Theoretical-Methodological Alignment

\begin{tabular}{|c|c|c|c|}
\hline History & $\begin{array}{c}\text { Lefebvre's spatial } \\
\text { theory }\end{array}$ & $\begin{array}{c}\text { Discourse } \\
\text { strategies }\end{array}$ & Effects on identity \\
\hline $\begin{array}{c}\text { Patterns of } \\
\text { meaning related } \\
\text { to the perception } \\
\text { of the town in the } \\
\text { national imaginary }\end{array}$ & $\begin{array}{c}\text { Conceived } \\
\text { (dominant) Space }\end{array}$ & $\begin{array}{c}\text { Identity } \\
\text { Reproduction }\end{array}$ & $\begin{array}{c}\text { Entrenches } \\
\text { patterns of } \\
\text { meaning } \\
\text { associated with } \\
\text { town \& people }\end{array}$ \\
\cline { 2 - 4 } & $\begin{array}{c}\text { Lived } \\
\text { (transformative) } \\
\text { Space }\end{array}$ & $\begin{array}{c}\text { Identity } \\
\text { Transformation }\end{array}$ & $\begin{array}{c}\text { Disrupts patterns } \\
\text { of meaning } \\
\text { associated with } \\
\text { town \& people }\end{array}$ \\
\hline
\end{tabular}




\section{Data Reduction}

Educators made numerous references to local place throughout the year. The first step in data reduction was to isolate all instances of place-based meanings evoked by educators. The unit of analysis is the short linguistic unit whereby educators mentioned Roche Bois directly or indirectly (e.g., through adverbs of place like "here" or spatial clauses such as "in your town"). To order and make meaning of the large number of instances where place was mentioned, the second step clustered place-based linguistic units into themes. These included children's homes, school, local rivers, hygiene and the body, the local highway, a waste-compacting facility where families rummaged for used goods, and industrial factories. Third, across the data set, for each theme I examined educators' use of predicative (qualifying, evaluative) language that qualified Roche-Bois with adjectives or adverbs of value and morality and, by extension, associated the children and their families with these values. Finally, I determined which discursive strategy was at work in the place-based references in relation to the larger history and outsider perception of the township, and whether the places produced were conceived or lived spaces, as in Table 1.

\section{Findings \& Analysis}

Starting with tracing the history of the town as an important contextualizing force shaping school-based meanings, I describe how changing demographics and events shaped the perception of Roche Bois in the national imaginary. This narrative of place is purposefully included in the findings to emphasize that context is not just a larger outside frame for social practice but is, instead, central to the production of meanings in school. Then, turning to ethnographic data from educators, I discuss how discourse perpetuates or transforms children's placebased identities.

\section{Becoming A Paradigmatic Creole Space}

The meanings of Roche Bois have become associated with Creole identity in the national imaginary, making the township a paradigmatic space of Creole identity. This was not always the case. How did demographic changes accompanied by changing perceptions produce this paradigmatic space? During the eighteenth and nineteenth centuries under French and British colonizations, Roche Bois was populated by diverse peoples of Indian and African origin. Early perceptions of Roche Bois as an exclusively Creole space began in 1960 after the destructive cyclone Carol contributed to widespread destruction of homes, with the accompanying relocation of many Creoles to the newly built government township (cité) in Roche Bois. At that time, many outsiders condemningly saw Roche Bois 
as a place where Creoles "had everything done for them" (Boswell, 2006, p. 137). Later, the forced relocation of refugees from the Chagos islands from the 1960s to 1971 augmented the perception of Roche Bois as an ethnically homogeneous space since Chagossians are racialized as Creole (Fanfan, 2000). The dire conditions of poverty and marginalization that the Chagossian faced contributed to the increased perception of the place as poor and destitute, with many accompanying stereotypes of promiscuity, crime, violence, and illiberal behavior.

Two months prior to independence from the British in 1968, ethnic tensions mounted in Mauritius, and clashes erupted between Muslim and Creoles who were living side by side in both Roche Bois and neighboring Plaine Verte. These events are known locally as the bagarres raciales (racial conflicts). The clashes caused many Muslims of Roche Bois to move to neighboring Plaine Verte, and many Creoles to relocate to Roche Bois. This migratory process increased the Creole population of Roche Bois, strengthened ethnic segregation, and affected the perception of Roche Bois as Creole. In the 1990s, a national movement embodied by a discourse called "the Malaise Créole" emerged, which expressed the Creole community's long-standing demands for social and economic equality in Mauritius. Contextualized in this movement, Roche Bois had in 1999 become the locus of the struggle when national-scale revolts erupted related to the death of the charismatic Creole singer Kaya under police custody. The revolts contributed to solidifying a hegemonic narrative about Roche Bois being a paradigmatic space of Creole identity. Today, it is a community that still struggles with environmental and social injustices, with the presence of numerous industrial processing zone factories dotting the landscape, a waste compacting facility, and longstanding stereotypes of lack of hygiene, poverty, crime, and violence reinforced in the national imaginary.

\section{Teaching about the Local}

The following four sections each highlight representative instances of themes that were instantiated as educators drew on local examples. The DHA I employed revealed that a large majority of place-based meanings were associated with aspects of Creole identity. Most meanings negatively racialized the children. A few moments of production of lived spaces occurred in which educators used positive place-based meanings, but these were not typical.

\section{Fixing Identities}

Throughout the year, as part of the national curriculum, educators taught the intricacies of Mauritian cultures, which included an overview of ethnic, religious, and ancestral identities that make up the social landscape of the island. In particular, in fourth grade, the history and geography curriculum includes a unit on locality. A typical instance of patterns in educators' speech about culture and locality occurred in the process of introducing Mauritius' multicultural landscape to 
students. The educator had taught about the multiple religions of Mauritius, and the review included the following conversation:

Educator: In Mauritius, there are different ways of praying, different ways of eating, different ways of living. Why do you think that is? Why? [...] Why does Danny [a pupil] go to pray in a church in Roche Bois and I go to pray in a temple? Why? Is that the same religion?

Students (together): No.

Educator: Why? Each person has a religion. Anabelle, when she goes to her parties in Roche Bois, she wears a short skirt, I would wear long clothing. Why are our ways of dressing different? (slight pause) - Because she is allowed to do this in her religion [Catholic], whereas in my religion [Hinduism], I cannot do this.

In this conversation, the educator discusses how religion determines a set of cultural practices (in this case, clothing). The educator is drawing on students' life examples from the locality to show Christian religious affiliation and culture. Yet in the educator's presentation of different identities to students, a stark contrast is created between the teacher and the students through pronouns: I/we versus you/them. Another feature of this discourse is that different Mauritian identities are presented in relativistic terms through the word "difference," a word that is used four times. When identities are represented as relative to each other and on the same level, a kind of flattening occurs. Relations are depicted as ahistorical and devoid of power dynamics. By presenting the Mauritian social texture as an inventory of identities relative to one another, the legacy of unevenness in access to symbolic, cultural, and material resources may also be hidden.

Educators had described the teaching of Mauritian history as especially challenging and sought resources to be better informed. However, it is clear here that the representation of identities aligns directly with the ways dominant Mauritian public perception conceptualizes fixed and homogeneous identities. In the dominant view, identities are immutable and hermetic. There cannot be any cultural mixing or complexity in the form of Creole-Hindus or Chinese-Muslims, for example. Cultural mixing, or "metissage," which was the very basis of the historical construction of the category of Creole, was not addressed in this classroom or any other classroom, thus leaving no room for students to imagine cross-cultural nuances in ethnicity, syncretism, or hybridity in their own identities within Roche Bois. Through this language, students are led to inscribe themselves within a spatial identity framework that posits monolithic identities as the norm. 


\section{Place and Racialized Bodies: Hygiene}

Of all the themes of place mentioned by educators throughout the year, the question of hygiene was the one that carried the most explicit negative racialization through its highlighting of children's somatic features. Many Roche Bois residents, like people living in other places in the world impacted by environmental injustices, struggle with health issues. Surrounded by factories that produce highly toxic commodities such as fertilizers and matchsticks, many children I observed suffered from skin infections on their hands and feet. These issues did not go unnoticed at school. All the educators I spoke to informally expressed concern about children's health, although this was not understood structurally through the lens of environmental (in)justice but rather as a child's or family's individual problem and as a problem to blame on the people in Roche Bois.

As an example, on the morning of the first day of the second trimester, as children came back to school after vacation, one educator started the following speech:

You need to work hard, you need to come to school, you need to come to school clean here. It's very important to be clean. Even animals are clean! Even the pig, the dog, when they roll themselves in the earth, it's actually to remove all the bugs on their bodies. [...] When you are clean, you will feel free.

The educator's language tries to convince children of the importance of cleanliness. The adjective clean is mentioned four times throughout the excerpt, and modal verbs such as "you need" are repeated several times at the beginning. To intensify the argument and relate it to the children's knowledges, the educator constructs a comparison with common animals found in Roche Bois, with the intensifying adverb "even." The logic is that animals are clean and therefore children should be clean. In fact, animals are posited as cleaner than children, as the model of cleanliness the children should follow.

While it could be understood that the comparison to animals was a way to demonstrate that every living being practices hygiene, the use of an animal trope associated with Roche Bois children and uncleanliness is part of a larger pattern of racist constructions of Roche Bois described earlier. Scholars have affirmed this same interpretation (André, 1997; Boswell, 2014; Easton, 1997; UNDP, 2008). In addition, the association of subaltern groups of people with animal tropes falls in the trajectory of a long, well-documented history of racism and colonialism in various tropical contexts (Stepan, 2006).

\section{Local Work, Menial Jobs}

Another theme in educators' representations of children in Roche Bois involved economic activity. Many of the examples used by educators were 
examples drawn from the local work of their families. A unit on locality in 5th grade focused on questions of work and economic activity in children's localities. One morning, the educator introduced the ways localities and histories shape people's economic activities by using local professions of Roche Bois and neighboring town Baie du Tombeau.

Educator: In any neighborhood, people have different kinds of work. For example, at Baie du Tombeau there is the ocean, so what do most people do there? They are fishermen. In Roche Bois, you will find some people are construction workers, some people are workers in the factories. Some people in Roche Bois work... I don't know, in sugar cane fields. There are several professions. Do all people have the same job?

Students (together): No

Educator: Certain people in Roche Bois work in Port Louis, in restaurants, or in the city, I don't know... to work at the movie theater.

The educator, while drawing on local employment examples that the children were likely familiar with, depicts an overall functionalist view of place linked to economic labor. In this sense, factories are depicted as the only self-evident provision of labor in Roche Bois. Children learn about the situatedness of economic production (fishing) related to the availability and proximity of natural resources (ocean). In fact, only these two localized Roche-Bois-based occupational sectors (factories and fishing) were mentioned during the year. While these associations may be relevant to some children, it is important to point out that the profession of fishing is stereotypically associated with Creole identity in Mauritius. Moreover, the educator's focus on the local here seems to be on "what jobs are available" as opposed to what jobs could be available and what children may envision becoming. Resorting to stereotypical local jobs may shut out other emancipatory possibilities and imaginings for children.

\section{Local Hybrid Identities}

Although the majority of instances described above negatively racialized children, there were select moments that disrupted dominant modes of spatial racialization. These moments were few, but they demonstrate that discourses of racialization through place are not totalizing and, more importantly, they point to possible decolonial models of action for teachers. A dialogue between two educators during a lesson on the use of local spices in 6th grade shows both reproductive (Educator B) and transformative (Educator A) discourse.

The class was discussing the use of nutmeg in the children's parents' home cooking and in particular in the dish called Briani. The flavorful rice dish blends spices such as nutmeg, cardamom, cloves, mint, garlic, and ginger, and is ethnicized as an Indo-Muslim dish in Mauritius. However, like many other 
ethnicized dishes, the majority of Mauritians--regardless of ethnic affiliation-- enjoy Brianis bought from street vendors or cooked at home. Because Briani is known and enjoyed widely, this dish, while being specifically ethnic/religious, also represents universal nationalism in Mauritius. One educator had brought a number of different spices for the children to smell and taste. Consider the interaction below:

Educator A Look for nutmeg. Does your mom use this spice at home?

Students Yes!

Educator A What do we put nutmeg in?

Educator $B$ What's this? Nutmeg?

Educator A Yes, we use this at home.

Educator B Really? Even here in Roche Bois? No one uses that spice here, no one uses it.

Educator A (turns to students for confirmation)

Who uses nutmeg at home? What do you do with it? What dish do you use it in?

Students In Briani!

Educator A Exactly! I too put nutmeg in my Briani.

Educator B I've never seen that occuring in Roche Bois.

Educator A Yes, but really, we use it in Briani.

Educator B They don't use that here, teacher, they don't.

Here, Educator A takes an inclusive stand toward the children, and this position merges his culinary knowledge with the children's. This process of bringing knowledges together is evidenced by the educator's inclusiveness use of "we," three times throughout the dialogue, and the comparative association of the educator with children in "I too." Through non-rhetorical questions to students about their actual food/culinary practices at home, Educator A defends children's knowledge of Muslim-Indian Mauritian culture as a form of local culture that children have prior knowledge of. Educator A's utterances discursively allow children to embrace an identity beyond a narrow definition of Creolity to which are assigned very specific foods and cultural practices. Inclusive language that draws on local realities creates a "we-ness" between Educator A and the children. In contrast to many instances analyzed in the previous section, this we-ness can be the basis for forging a new sense of local community: one in which educators and students are made close by the sharing of similar multicultural knowledges and one where diverse cultural practices are valued despite ethnic/religious differences.

In contrast to Educator A's inclusiveness, Educator B's utterances are othering, and perpetuate patterns of negative spatial racialization frequently observed at school. By using the pronoun "they" twice toward the end of the dialogue, as well as "no one here" in front of the children to speak for them, the 
educator is creating a divide between educator and children's knowledges. Children's local knowledges here are confined to an emplaced racialized identity connected only to Roche Bois and being Creole. This aligns directly with dominant unitary tendencies to emplace children in Roche Bois as monolithic identities.

During the year, there were several other moments where educators presented children as knowledgeable about multiple religions and plurilingualism. These moments of lived space are, as Soja (1996) describes, "'counterspaces,' spaces of resistance to the dominant order arising precisely from their subordinate, peripheral or marginalized positioning" ( $p$. 68). Lived space, then, becomes a "strategic location from which to encompass, understand, and potentially transform all spaces simultaneously" (Soja, 1996, p. 68). It is these moments of teacher discourse that may serve to theorize what a critical place-based pedagogy may look like in this context.

\section{Conclusion}

\section{Theorizing Race}

The process of identifying educators' references to place and accompanying qualifying language showed that the large majority of instances where Roche Bois was mentioned directly or indirectly across educators' discourse were deeply value-laden because they were associated with the historical racialization of Roche Bois as a space of Creole identity. We can thus speak of spatial racialization through discourse.

Further, this process of spatial racialization takes shape not through a singular topic but through an amalgamation of themes. These include hygiene, employment, and fixed identities. Taken individually, the thematic dimensions do not in and of themselves constitute processes of racialization. Together, however, they weave together qualitative codes associated with place to show the "chameleonic" and polyvalent nature of racial meanings. Therefore, processes of racialization do not necessarily stand on one trait or characteristic. They are systems of signification that are anchored in various thematic dimensions that are often spatialized in specific contexts.

Together, through Lefebvre's lens, these themes collectively constitute "conceived spaces," because they are patterns of reproduction of Creole identities anchored in the context of Roche Bois and they perpetuate the negative racialization of Creole children. Conceived spaces produced by the institutional power of the school are powerful meanings that align themselves with historical stereotypes and dehumanizing perceptions of Roche Bois. Educators play a role in maintaining spatial imaginings that "frame" children in negative ways-despite the good intentions associated with the use of the local-and limit the possible imaginings of their spaces, bodies, cultures, and activities. 
The findings also demonstrate that place, as a category of signification, is a discursive terrain onto which ideas of society and race are articulated. Places are not innocent; they are agential, as they are generative of meanings. Because the meanings of places have been structured through larger historical processes, what happens in a given place at a given time occurs as one moment in the collection of meanings that were produced prior to that particular event. That moment is part of a process of sedimentation of meanings over time. The history of Roche-Bois plays a role in the homogenizing framing of students who live there. Even non-Creoles who live in Roche-Bois were subsumed within what could be called a dominant "grid of intelligibility" (Foucault, 1976/1978), a kind of hardening of meaning. Despite educators' constructivist framing of using the local in ways that are relevant to children's realities, hegemonic meanings of spatial racialization shape the meanings they produce about Roche Bois children.

\section{Implications for Teacher Education}

Fortunately, transformative lived space is also evident in a few moments of educators' discourse whereby open identities are created for children. The production of lived space demonstrates that there is openness in the discursive configuration of Roche Bois, that it is possible to represent it in non-totalizing ways. These representations point to decolonial educational practices that many advocate for from different approaches (Battiste, 2016; Gruenewald, 2003; Guajardo, Guajardo, Janson, \& Militelo, 2016).

A decolonial practice would reinvest the local with critical historical meaning, which would affirm children's grounded, yet open-ended, identities and form the basis for a pedagogy of decolonization. In his seminal theorization, Gruenewald (2003) envisioned a pedagogy of decolonization as a political practice that learns to recognize injury and oppression in places and to unlearn oppressive histories and narratives. A pedagogy of reinhabitation seeks to practice more socially and ecologically just ways of being in the world. In a decolonizing pedagogy for Roche Bois, teachers would be supported in developing their context-specific critical knowledges of the local as a way to re-learn place-based knowledges that have been shaped historically. This pedagogy would remedy the pitfalls of what I term "the pedagogical present" in educational practice, which is the belief that teachers are able to draw on students' local experiences "on the fly," in the immediacy of speech during teacher-student interactions.

Instead, with great care, educators should be formally supported in learning about multiple perspectives on the specific places they teach in - in other words, developing critical histories of place or what some have termed a "context-specific education" (Matsko \& Hammerness, 2013). In the context of Mauritius, there are several frameworks that might guide the implementation of teachers' development of a critical history of place. These include Freirean cultural circles (Souto Manning, 2010), Community Learning Exchanges (Guajardo, Guajardo, Janson, \& Militelo, 2016) or Funds of Knowledge (Gonzales, Moll, \& Amanti, 2005). These models 
may promote teacher learning beyond school boundaries to expand their range of perspectives on place. The specification of what multiple local perspectives looks like would need to be determined according to the dynamics of each school and could not be predetermined through centralized or standardized teacher training. To use Deweyan language, decolonizing practices would fund the knowledge of the teacher toward disrupting the powerful conceived spaces that produce many teachers' meanings and expand possibilities for the production of transformative lived spaces for students.

\section{References}

André, N. (1997). Exclusion et gestion de la quotidienneté [Exclusion and management of the everyday]. In I. Asgarally, Etude pluridisciplinaire sur l'exclusion à Maurice [Pluridisciplinary study on exclusion in Mauritius] (pp. 65-85). Réduit, Mauritius: Government Printer.

Aulette, J.R. (2016). A global view of race and racism. New York, NY: Oxford University Press.

Battiste, M. (2016). Decolonizing education: Nourishing the learning spirit. Saskatoon, Canada: Purich Publishing Limited.

Boswell, R. (2006). Le Malaise Créole: Ethnic identity in Mauritius. New York: Berghahn Books.

Boswell, R. (2014, June). Can justice be achieved for slave descendants in Mauritius? International Journal of Law, Crime, \& Justice. 42(2), 146-161.

Bunwaree, S. (1997). Education and exclusion. In I. Asgarally, Etude pluridisciplinaire sur l'exclusion à Maurice [Pluridisciplinary study on exclusion in Mauritius] (pp. 139-178). Réduit, Mauritius: Government Printer.

Cresswell, T. (2004). Place: A short introduction. Malden, MA: Blackwell.

Cole, R. (2008). Educating everybody's children: Diverse teaching strategies for diverse learners (2nd ed.). Alexandria, VA: Association for Supervision and Curriculum Development.

Dabach, D.B., \& Fones, A. (2016). Beyond the "English Learner" frame: Transnational funds of knowledge in social studies. International Journal of Multicultural Education, 18(1), 7-27.

Delpit, L. (1995). Other people's children: Cultural conflict in the classroom. New York, NY: The New Press.

de Cillia, R., Reisigl, M., \& Wodak, R. (1999). The discursive construction of national identities. Discourse and Society, 10 (2), 149-173.

Dewey, J. (1938). Experience and education. New York, NY: Touchstone.

Easton, G. L. (1997). Mémoire et exclusion [Memory and exclusion]. In I. Asgarally, Etude pluridisciplinaire sur l'exclusion à Maurice [Pluridisciplinary study on exclusion in Mauritius] (pp. 49-65). Réduit, Mauritius: Government Press. 
Emdin, C. (2016). For white folks who teach in the hood... and the rest of $y$ 'all too. Boston, MA: Beacon Press.

Eppley, K., Shannon, P., \& Gilbert, L. K. (2011). "Did you like living in a trailer? Why or why not?". Discourse and the third space in a rural pen pal exchange. Teaching and Teacher Education, 27 (2), 289-297.

Fanfan, M. M. (2000). Youth problems in Roche Bois (Unpublished Doctoral Dissertation). University of Mauritius, Réduit, Mauritius.

Foucault, M. (1976/1978). The history of sexuality, vol. 1: An introduction. New York, NY: Vintage Books.

Fraser, N., Dahl, H.M., Stolz, P., \& Willig, R. (2004). Recognition, redistribution and representation in capitalist global society: An interview with Nancy Fraser. Acta Sociologica, 47(4), 374-382.

Geertz, C. (1973). Thick description: Toward an interpretive theory of culture. In C. Geertz, The interpretation of cultures: Selected essays (pp. 3-30). New York, NY: Basic Books.

Gieseking, J.J., Mangold, W., Katz, C., Low, S., \& Saegert, S. (2014). The people, place, and space reader. Retrieved from https://peopleplacespace.org/

Gilroy, P. (1987). Race, class and agency. There Ain't No Black in the Union Jack: The Cultural Politics of Race and Nation, 15-42; Chicago, IL: The University of Chicago Press.

Gruenewald, D. (2003). The best of both worlds: A critical pedagogy of place. Educational Researcher, 32 (4), 3-12.

Gruenewald, D., \& Smith, G. A. (2008). Place-based education in the global age. New York, NY: Lawrence Erlbaum Associates.

Goldberg, D. T. (1993). Racist culture. Cambridge, MA: Blackwell.

Gonzales, N., Moll, L., \& Amanti, C. (2005). Funds of knowledge: Theorizing practices in households, communities, and classrooms. New York, NY: Routledge.

Guajardo, M., Guarjardo, F., Janson, C., \& Militello, M. (2016). Reframing community partnerships in education: Uniting the power of place and wisdom of people. New York, NY: Routledge.

Hammerness, K., \& Craig, E. (2015). Context-specific teacher preparation for New York City: An exploration of the content of context in Bard College's urban teacher residency program. Urban Education, 51(10), 1226-1258.

Hedges, H. (2015). Sophia's funds of knowledge: Theoretical and pedagogical insights, possibilities, and dilemmas. International Journal of Early Years Education, 23(1), 83-96.

Hogg, L. (2011). Funds of knowledge: An investigation of coherence within the literature. Teaching and Teacher Education, 27, 666-677. 
Hogg, L. (2016). Applying funds of knowledge theory in a New Zealand high school: New directions for pedagogical practice. Teachers and Curriculum, 16(1), 49-55.

Jensen, E. (2005). Teaching with the brain in mind (2nd ed.) Alexandria, VA: Association for Supervision and Curriculum Development.

Lefebvre, H. (1991). The production of space. Malden, MA: Blackwell.

Macias, A., \& Lalas, J. (2014). Funds of knowledge and student engagement: A qualitative study on Latino high school students. In Our House articles, poems, and short stories. Retrieved from http://inspire.redlands.edu/oh_articles/118

Marlowe, B., \& Paige, M. (2005). Creating and sustaining the constructivist classroom. Thousand Oaks, CA: Corwin Press.

Matsko, K. K., \& Hammerness, K. (2013). Unpacking the 'urban' in urban teacher education: Making the case for a context-specific education. Journal of Teacher Education, 65(2), 128-144

Moll, L., Amanti, C., Neff, D., \& Gonzales, N. (2005). Funds of knowledge for teaching: Using a qualitative approach to connect homes and classrooms. In N. Gonzales, L. Moll, \& C. Amanti, Funds of knowledge: Theorizing practices in households, communities, and classrooms (pp. 71-89). New York, NY: Routledge.

Nespor, I. (2008). Education and place: A review essay. Educational Theory, 58(4), 475-489.

Omi, M., \& Winant, H. (2015), Racial formation in the United States (3rd ed.). New York, NY: Routledge.

Truth and Justice Commission (2011). Report of the Truth and Justice Commission, Vol. 1.1 Mauritius. Retrieved from https://www.usip.org/sites/default/files/ROL/TJC_Vol1.pdf

Salverda, T. (2010). Sugar, sea, and power: How Franco-Mauritians balance continuity and creeping decline of their elite position. (Doctoral Dissertation). Vrije Universiteit, Amsterdam.

Sanchez, J. C. (2018). Trump, the KKK, and the versatility of White supremacist rhetoric. Journal of Contemporary Rhetoric, 8(1/2), 44-56.

Soja, E. W. (1996). Thirdspace: Journeys to Los Angeles and other real and imagined places. Malden, MA: Blackwell.

Souto-Manning, M. (2010). Freire, teaching \& learning: Culture circles across contexts. New York, NY: Peter Lang Publishing

Steiner-Khamsi, G. (2015). Teachers and teacher education policies. In T. McCowan \& E. Unterhalter (Eds.), Education and international development (pp. 149-168). London, UK: Bloomsbury.

Stepan, N. L. (2006). Picturing tropical nature. Ithaca, NY: Cornell University Press. 
Stoler, A. (2002). Carnal knowledge and imperial power. Berkeley, CA: University of California Press.

UNDP (2008). SGP The Small Grants Programme: Waste disposal scheme for Roche Bois. Retrieved from https://sgp.undp.org/index.php?option=com_sgpprojects\&view=projectdet ail\&id=9464\&ltemid $=272$

UNICEF. (2000). Defining quality in education. Retrieved from http://www.unicef.org/education/files/QualityEducation.PDF

Varga-Dobai, K. (2018). Remixing selfies: Arts-based explorations of funds of knowledge, meaning-making, and intercultural learning in literacy. International Journal of Multicultural Education, 20(2), 117-132

Willis, J. (2012). A primer: Neuroscience and teaching strategies. Retrieved from http://edge.ascd.org/blogpost/a-primer-neuroscience-and-teaching-strategies

Wodak, R., \& Reisgl, M. (1999). Discourse and racism: European perspectives. Annual Review of Anthropology, 28, 175-199.

Wodak, R., \& Reisigl, M. (2001). Discourse and discrimination. London, UK: Routledge.

Wodak, R., \& Reisigl, M. (2009). The discourse historical approach. In R. Wodak \& M. Meyer, Methods of critical discourse analysis (pp. 87-122). London, UK: Sage.

\section{Author Contact}

Elsa Wiehe, elsawiehe@gmail.com 